\title{
The Borders of Borders
}

\section{Christianity and the Rethinking of Public Space}

\author{
Kurt Appel \\ Department of Fundamental Theology, Faculty of Catholic Theology; \\ Research Centre Religion and Transformation in Contemporary Society, \\ University of Vienna, Schenkenstraße 8-10, 1010 Vienna, Austria \\ kurt.appel@univie.ac.at
}

\begin{abstract}
This article examines the significance of public space for the European project and reflects on the contribution of Christianity to the shaping of today's public space. It is characterized by a common and shared symbolic, social, cultural, economic, political and geographical sphere that is potentially accessible and open to all people and welcomes creative participation. Today the specific task of Christianity consists not at least in the concretization of the idea of universal friendship in view of an ethos of empathy and inclusion which is perceptive of migrants and their narratives. The development of a amicable and non-hegemonic coexistence of Christianity, Islam and the secular world in Europe poses a particular challenge. In addition, it is necessary to make one's own traditions and potentials fruitful in such a way that also the dead, who in the secular world are largely excluded, obtain a corresponding presence in the world of the living beyond nihilistic resignation. In this context it becomes apparent that the vocation of Christianity consists in providing an exit strategy to closed social and symbolic worlds. This exit includes the subversion of boundaries. It does not create an abstract boundlessness, but sets in motion a continuous process of creative openings and shifts in which public space becomes concrete as a place of ever new approaches, exits and inclusions.
\end{abstract}

\section{Keywords}

public space - exit strategy - Christianity - Islam - boundaries - subversion of boundaries - postnihilistic narratives - Europe 


\section{Public Space as Essence of the European Project and its Nihilistic Challenge}

This paper aims to demonstrate that any new narrative for Europe must, in a very particular way, address the issue of public space, ${ }^{1}$ i.e. a space of cultural, religious, societal, economic, and social interaction in which everyone can freely participate. In this sense the public space is the representation of European Culture. If Europe's cultural landscape is shaped by a large and multidimensional memory of human vulnerability, if Europe is founded upon grand narratives of the consciousness of freedom (the Greek, the Judeo-Christian, the Enlightenment, etc.), if Europe possesses a universal significance, one that extends well beyond its borders, then it is because the European project is inseparably bound to a civil-societal, cultural, and finally, Christian/Judeo-Christian/ Abrahamitic vision. This is a vision of nothing less than the possibility of all (wo)men to freely encounter one another in a common place, from which no one is excluded. In this place there are "no Jews or Greeks, no slaves or freemen, no men or women" (Gal 3:28).

Of course, we cannot pass over in silence the fact that Europe was not only the site of the most brutal wars, but is also the scene of the most excessive nihilism. This European nihilism - the perverted aspect of the European consciousness of freedom - is characterized by the view that all boundaries, all cultural traditions and relations, all their real content, have to be annihilated. The European can detach himself from everything and everyone, with the consequence that no object, no history, no boundary, no man, i.e. "nothing" possesses absolute validity for him. It is no coincidence that, as a result of this mindset, freedom itself is being transformed under the new pressures of an increasingly virtualized neoliberal world, in which all contents are interchangeable. As a result, there is an uncompromising struggle against any residual elements that attempt to hold

1 For the essential importance of civil society and public space, see the classical and unsurpassed study by Habermas 1991. In recent times, Saskia Sassen has written some books which are of particular interest for the topic of public space. In the magnum opus "Global networks, Linked cities" (Sassen 2016 [2002]) which she edited, the shaping of new megalopolis and the influence of globalisation, neoliberalism and new technologies is paradigmatically described. Of great significance is the observation that the (public) space shaped traditionally by the state (or the nation) becomes more and more dominated by supranational entities, "such as global electronic markets and free trade blocks" (Sassen 2016 [2002], pp. 1-38, here: p. 9). Another book to be mentioned is David Harvey's Rebel cities (Harvey 2012). In the second part of his work Harvey shows (with reference to the Bolivian city El Alto) the potential of urban resistance against the disappropriation of public property and the shaping of new solidarian (public) spaces. 
onto specific content (e.g. in the area of religion). A new narrative of European civil society - as defined by the existence of public spaces - cannot turn back to either heteronomous premodern structures and their limits, which excluded free encounters and universally accessible spaces, or to a narrative that negates the nihilistic potential of the European consciousness of freedom.

\section{2 \\ The Idea of Universal Friendship and the Sacred as Surplus not to be Represented and Dominated - A Biblical Contribution to the Concept of Public Spaces}

The idea of a universally accessible public space ${ }^{2}$ is none the least connected with the historical background of the biblical tradition and its secular transformation. One could stress that in the ethos of the gospel there was, for the first time ever, a group (namely the early Christians) who were empowered to befriend any person (transcending the boundaries of gender, nationality, or social standing), and to potentially call any person a friend. ${ }^{3}$

The background to this ethos is to be found, to begin with, in the life of Jesus. Sent to the lost "sheep" of Israel, he proclaimed the 'Basileia' (the kingdom of God) which included even the crippled, the sinners and the eunuchs (at the time a kind of 'third gender' beyond the dichotomy of man/woman and despised by all), i.e. all social outsiders.

Besides this new configuration of the boundary between inclusion and exclusion, a further moment demands attention, one that carried great weight for understanding boundaries and transgressions of borders in the Bible. To move beyond the inclusion-exclusion dichotomy, this moment may be characterized as a theocentric (because it is not controllable by man) surplus (biblically known as the "rest"4) that decisively shapes the understanding of boundaries in the Bible. This motif plays an important role as early as the

2 The theologian who was one of the first to formulate decisive impulses on this debate is David Tracy; see his path-breaking book: The Analogical Imagination: Christian Theology and the Culture of Pluralism (Tracy 1981). In Europe the work of Johann Baptist Metz is of particular importance for the connection between public space and theology. The memory of the suffering of the other and Metz' plea for narratives including the history of the oppressed and the marginalized open fields of solidarity which are essential for real public spaces not belonging to the dominating classes. See Metz 2006.

3 See Illich 2005 .

4 Crucial for an understanding of boundaries and borders forged on biblical depictions of inclusion and exclusion are the works of Giorgio Agamben and Jean Luc Nancy: Agamben: $I l$ tempo che resta. Un commento alla "Lettera ai Romani" (Agamben 200o); Nancy: La déclosion. Deconstruction du christianisme, 1 (Nancy 2005). How these boundaries are approached in 
account of Creation in the Bible: 5 the seventh day is a divine surplus to the six-day week, one that does not add any genuine new substance, but instead radically opens up chronological time or Creation (expressed through and in the first six days) to God's future advent. In this way, the seventh day - lying neither within nor beyond the six days ${ }^{6}$ - becomes the messianic day, expressed in the Gospels by how Jesus heals on the Sabbath. And the reason he does so is not to wrest a liberal interpretation of Jewish Torah from his opponents, but because the seventh day is the day that the Messiah will arrive and Creation will joyfully be configured anew. The tree of knowledge in the second account of Creation (Genesis 2,4b-3) plays a similar role. As close consideration of the text shows, ${ }^{7}$ the tree is situated at the centre of the garden (as if it were a doppelganger of the tree of life which - like a deity radiating across the world - allows all being in its garden to participate in its life); at the same time however, the tree of knowledge is the garden's beyond, whereby the ambiguity (see footnote 7 above) is intentional. The surplus, expressed temporally through the Sabbath and spatially through the tree of knowledge, defies direct representation and inscribes an opening in the spatial-temporal events. Because this surplus of the seventh day or the tree of knowledge constitutes time or space, neither space nor time can be identical with their representation. In other words: the categorical world is never fully identical with itself, all the boundaries signified in it (the diversities of the days and places) have their "otherness" inscribed in them, thus preventing the boundary marking of inclusion and exclusion from ever becoming absolute. The One Day ${ }^{8}$ constituting time and the tree of life constituting space, which assign and set the boundaries of space-time, are each related to their other and stand in its openness. The sacred is thus not a separated or detached space, which can be clearly and

the mysticism of the modern age and symbolic spaces are created is brilliantly shown by Michel de Certeau: Le fable mystique, 1:XVI ${ }^{e}-X V I I{ }^{e}$ siècle (Certeau 1982).

5 See Appel 2015, pp. 19-6o.

6 This is expressed in the Christian liturgy in the figure of the Sunday, which as the "eighth day" designates both the festive, holy seventh and the profane first day, i.e. coincident with the first day, it is its opening and transcending.

7 "Out of the ground YHWH God caused to grow every tree that is pleasing to the sight and good for food and the tree of life in the midst of the garden and the tree of knowledge". (Gn 2:9) The second 'and' can be read both as coordinate to the tree of life (i.e. the tree of knowledge is, parallel to the tree of life, situated in the middle of the garden) and also as a coordinate to the whole garden: in this case, the tree of knowledge is beyond the horizon of the garden.

8 The biblical text is consequent in not speaking about the creation of a "first day"; rather, the first work expresses the "One Day" as the constituting moment of Creation. Gn 1,5b: "and there was evening and morning”: one day (not first day!). See Zenger 1983. 
definitively demarcated from the profane, but it is the sacrosanct surplus to the profane itself, enabling the profane to configure anew.

Two Threats of Public Space: The Dominance of the "Chosen Few" and the Omnipresence of the Infinite

This has enormous repercussions for how the infinite is conceived. A classical perspective would either juxtapose the infinite to the finite (whereby it would once again be finite) or it would plain and simply annihilate the latter. In relation to public space, the consequence in the first case is the dominance of a sacralised domain of the other, divested from the finite. It would be administered by "the chosen few" who draw their legitimacy from the established dichotomy between the redeemed on the one hand (in the case of Europe: the Christians, men, or national citizens) and the excluded on the other (the Jews and the Muslims, women, foreigners, etc.). In the second case, the consequence is the ubiquity/omnipresence of the infinite, i.e. the annihilation of all that is finite by a centre wherein all power is concentrated. In this case, a gapless virtualization of everything finite takes place, conjuring the "Big Other", one that however would be out of the finite's view (and thus be out of reach of all democratic controls). The consequence would be a world of appearance, one in which there is no longer any way out, no exit, nothing open, a world in which everything is unlimitedly presentable and available and yet only a semblance - without any reality (res aliter, the case of the other).

\section{$4 \quad$ Limitless and Openness or the Subversion of Borders}

We find both deformities of the infinite in the Gospels. In the Gospels, the scribes represent a system of exclusion, combined with the co-opting of the sacred. The "honour" of a person is tied to very specific modes of behaviour and social norms, while deviations from these ("sinners") are punished with ostracism from the community, from public life by the learned. The second deformity is encountered in demons: they represent an aperion, i.e. a form of the infinite that has obliterated all structure. Of particular interest is that, above all in the Gospel of Mark, it is the demons (and not Jesus' disciples or relatives) who are able to recognise Jesus as the Messiah (Mark, 1:24 ${ }^{9}$ ). With Jesus, they

9 The question of the demons, "What between us and you, Jesus of Nazareth", is not simply rhetorical. 
seem to share the ability to abrogate boundaries. While in the demonic case everything is steered and controlled by a transcendent superhuman power, it is a distinctive characteristic of Jesus that he created new openings, exit strategies against a heteronomous life and in this way new possibilities of participation. Whereas the limitlessness of the demons destroys every structure and every significance, the gesture of Jesus could be described as inscribing borders into the borders and in this way not creating an infinite madness but the openness as such. This means the subversion and deplacement of every border by shaping new structures based on a surplus which never can be possessed entirely. When Jesus insists that non even a jot will pass from the law (Mt 5,17) we must not forget that the "jot" is the beginning of the unpronounceable name of YHWH which must not be represented and pronounced. In this way Jesus insists that the law as structure of the symbolic space is embedded in the name of God which terminates the law and its borders. Strictly speaking, Jesus' gestures and teaching is not about the limitless (not even one of love), but about openness; that means a subversion of excluding borders (and their representations) and a creative recreation of spaces and times which are characterised by forms of participating involving those once excluded or exhausted with their lives. In a positive sense, one could say that Christianity, the Judeo-Christian tradition, the Abrahamic-monotheistic tradition is called on to reveal exits of dominated and closed realms and to lay open new possibilities of life and shared public spaces for hospitable meeting(s) by dealing with borders in a playful-creative manner.

In its historical form, Christianity is shaped by such new departures and by the subversion ${ }^{10}$ of life-destroying authorities and powers, but similarly time and again it was a project of exclusion (initially against above all Jews) or a suspension of borders in favour of an absolute claim to power. In opposition to it there admittedly arise dissident movements using biblical resources: secular Europe, the world of the Quran, socialism, and many more, which force a renegotiation of the boundaries and contribute to a scrutinising and challenging of the mechanisms of power and exclusion, out of which those public spaces of Europe emerge which are then plural.

Against this pluralised world stands the tradition of an all-encompassing claim to power, the possibility to eliminate all life, which finds its most massive expressive form in European nihilism. ${ }^{11}$ This manifests itself as virtuality, a

10 The subversive dimension of Christianity and Christian mystic is shown by Michel de Certeau (Certeau 1982).

11 Nietzsche probably has to be seen as the fiercest critic and prophet of the arising European nihilism. One could perhaps say that in the 2oth century fascism represents a 
virtuality in which the very matter of the other (the body) is utterly and completely extinguished - with all the ecological and political consequences this entails.

This raises the question of how to connect Christianity (and the secular traditions which partly have replaced Christianity) and civil society in a new post-nihilistic narrative for Europe. Furthermore, it leads to the question of Christianity's or religion's significance within civil society. This would then entail the necessity of determining the relationship between secular society and the religiously oriented world of sentiment and emotions. In the current societal context there is also the unuttered yet resonating question of how European societies are supposed to deal with the growing presence - at least in Western Europe - of Muslim citizens and migrants (and how Muslim citizens and migrants can deal with Europe). The question of Europe's future as a symbol of hope for a cosmopolitan society is inseparably bound to that last question. Can Europe still be seen as a project of peace or is it becoming a meaningless formula? Can Europe release liberate creative spaces from migration and ecological crisis, and thus yield new forms of the public sphere, or will it remain self-referential and a project of exclusion or encompassing virtualization and annihilation of the other?

Before I address these issues, I want to turn to one of the most significant events in recent years, namely the mass migration that has made an impact on all of Western Europe. Perhaps the most haunting image of this could be the mass arrivals of people from Africa and the Near- and Middle-East to the coasts of Europe and the migrations on foot across the Balkans. In 2015, Germany, increasingly the European Union's centre of power, chose a policy of acceptance. The decision not only meant finally recognizing that they are a dream destination for entire peoples and continents, but it also offered Germany the possibility for a kind of collective atonement for the crimes of National Socialism. The European Union's foundational narrative, which in a very specific way is also the central narrative for the Federal Republic of Germany, is that the unspeakable atrocities of National Socialism must never be repeated. In the events of

project of affirming identity by attributing inclusion (the nation) and exclusion. In contrast, National Socialism is characterised by an absolute nihilism: the 'Jew' must die; but because he is not really distinguishable from the German, and is at the centre of European and German culture, anyone can be declared a Jew deserving of death. 
2015, Germany wanted to show to itself and the world that it is an open and welcoming country, which sets its political priorities according to moral premises, and feels especially committed to human dignity. Remembering the victims of National Socialism demands a narrative of inclusion, an openness to the creation of public spaces which include those who have hitherto not found a place.

What ought to have been done in the wake of the events of 2015 in Germany and respectively in Europe at large is to give this happening a meaning that is directed into the future. It emerged that in Europe at large there existed a somewhat fragile consensus with respect to not falling back into a fascist and totalitarian politics. At the same time, it was obvious that the memory founding this consensus was eroding in case it was not fed with new visions and narratives.

Firstly, it has to be observed that presently Europe is marked by the homeless and those without "strong" identity (based on tradition, political participation, local culture etc.). Like shadows and ghosts, migrants cross the continent and populate the societal and topographic margins; they are catalogued in extensive surveys, yet they are still scarcely the subject of our collective cultural narration in the media. One of their sources of rendering an identity lies in the pretended or yet real religious tradition. Although it is difficult for migrants to feel comfortable in a continent in which traditional family structures and identities have partly dissolved and although it is even a greater challenge for many of them to come to grips with the incredible process of abstraction, which allows the Europeans to dissociate themselves from everything and everyone (happenings, individuals, traditions, commitments, cultural boundaries, even of gender, social imaginaries), there still exists in the realm of religion a kind of compensation ${ }^{12}$. In the eyes of many migrants, religious belief represents a superiority of their culture opposite the "godless" Europe and by this the chance of finding an identity within the sphere of God. However, even within the cultures of Europe, traditionally orientated on nations, an increasing insecurity can be observed. It seems as if, concomitant with the gained freedom, the loss of identity is compensated by consumption, virtual brand identities and the expulsion of others to secure one's own identity.

12 The failure of copying European rationality and resorting back to religious symbolic forms is strikingly told in Orhan Pamuk's novel Snow (Pamuk 2004). 

Secular World

Migration offers despite of all these problems a chance, which in itself presents a sort of moral imperative, if Europe is not to be destroyed by new civil and religious wars: it is the vision of a togetherness (alliance, bond) between the Jewish and the Christian tradition, Islam, and the secular world ${ }^{13}$, the vision of a new creation of expressive forms, perceptions, relations of recognition and narratives of integrative participation and sharing. In other words: Europe, and indeed the whole of Europe (a definite division between East and West would be a fatal flaw) must expand its historical task for the entire contemporary global community, to the effect that it not only leaves behind and prohibits its millennia-old anti-Semitism, but also ends the war between Christianity and Islam, which has been waged with varying degrees of intensity, and is now framed as a conflict between secular modernity and Islam. The task consists in allowing Islam entry into both the public and narrative space of Europe and its institutions, as well as the creation of a European Islam, a European Christianity (which means a Christianity which begins to interpret its depositum fidei in the light of Islam and Judaism as it interpreted its faith in the light of Hellenistic philosophy) and a European secularism, which all stand under the banner of 'co-existence.' In my view, Christianity has to act as a moderator between secular modernity and Islamic religion, and as an intermediary between reason and faith.

\section{Public and Private Sphere and "Europe" as an Immagine of the Exit of Immagines}

At this point, I would to examine the central proprium (social imaginary) of Europe, namely the question of public (civil) space and the (civil) society committed to it. The specific merit of European civil society consists in having designated public spaces, and making them accessible to all citizens ${ }^{14}$ : this not only pertains to the town tavern, or the parish institutions (which are still a prime example of public space in many countries), but rather the education, health, and transport services, cultural facilities, the police, sports facilities, legal services (no one should have his/her rights violated), recreation centres, etc.

13 For the task of rediscovering religion in modern society, see Berger 1970.

14 For urban planning and architecture see in particular the remarks by Denk 2017, pp. 263275 , here: pp. 263 et seq. 
Bound up with this culture of public space is the possibility to withdraw into the private sphere. Precisely because there are functioning public facilities for encountering others, one can also retreat from them. Here we touch upon an eminently significant piece of biblical heritage: precisely the personal, intimate relationship with God, the idea of an inner voice in the form of a conscience, and the experience of personal love and responsibility favoured the construction and cultivation of a private sphere, which represented the other side of the public realm. Recalling the reflections in sections 3 and 4, one can also maintain that the person represents the non-representable surplus, the openness that manifests in the creative shifting of boundaries. Only where the human is conceived in a way that no external attributions can determine him/ her, does he/she become the subject of a public that transcends all particulars (i.e. external attributions).

"Europe", if characterized by open public spaces and possibilities of withdrawal into the private sphere, might paradoxically represent the immaginary of an exit from all fixated immaginaries ${ }^{15}$. Maybe one of the promises of the project "Europe" could be the thought that there is no ultimate (institutional, statal, national, religious, cultural) representation of its meaning and that its vocation lies exactly in offering alternatives (exits) to every predetermined way of (social, individual, national or spiritual) life.

\section{Reviving Public Spaces}

Today public spaces are constantly eroding: they are being economically, physically and politically hollowed out and privatized - with visible and audible consequences (constant exposure to advertisements in public spaces, urban sprawl, environmental degradation, architectural indifference in the construction of public buildings, etc.). The privatization of the public has the paradoxical effect that the public penetrates more and more into private life, so that we are faced with a public display of the private, which entails an increasing indistinguishability between public and private. In this connexion, it is the virtualization of public spaces that particularly needs addressing: a generally accessible reality has been superseded either by an endless segregation of the spheres of life, eclipsing the idea of the common universal and pushing it into the background, or an abstract universality in which nothing at all really possesses any significance. This form of virtualization tends to eliminate the body of humans. Space and time, and thus the body in its resistive presence,

15 See also Neri 2014, pp. 183-203. 
no longer play a role in the virtual word; this world can be randomly and gratuitously modelled and distanced in accordance with one's own arbitrary wishes.

The great task of politics today would consist in reviving public spaces (as the representation of modern democracy), creating new forms of participation and keeping them accessible. This not only includes political positions on economic, environmental and security policies, but would also have to include a cultural and pedagogical programme: public spaces must be given aesthetic designs so that we can feel that they are liveable, that they are places for encounters and creative transformation. Respect for public spaces must be taught to school-age children. The state as well as the churches and the universities are of paramount importance here, since they are in a certain respect 'birthplaces' of our civil society.

\section{9 \\ Three Possible Contributions of Christianity: Empathy, Inclusion of the Dead and Providing an Exit-Strategy for the Living}

Religion(s) must never monopolize the civil sphere for its own purposes, and likewise religion(s) should never be excluded from the public. One could write a great deal about the function, the contribution, but also the dangers of religions in the construction and preservation of public spaces, but I limit myself to three areas, which seem to me especially important for a Christian narrative of the foundation of public space:

The first contribution Christianity has to offer, is a tremendous affective and narrative register ${ }^{16}$, an aesthetic programme which can be made fruitful for civil society (the same counts for Islam and Judaism). We must not forget that public spaces are based upon shared emotions, i.e. they presuppose a sort of mutual, basic sympathy and general empathy. Christianity, as a tradition, bears within it the potential to recognize vulnerability, belongingness, and the unattainability (Unverfügbarkeit) of life and it can also channel emotions towards empathy.

The second contribution seems underappreciated to me: Europe cultivated the idea of public space but in doing so it almost systematically excluded the dead. ${ }^{17}$ European culture is therefore more and more bound to the 'eternal

16 In our times it is especially Pierangelo Sequeri who considers this important heritage of Christianity (also with respect to the background of European Nihilism). See Sequeri 2016.

17 Johann Baptist Metz is the latest to object to this reduction of humans to the sphere of the living. See Metz 2006. 
present', i.e. Western culture has become virtually atemporal because death has no place in it. The various religions have monopolized the realm of the dead. This has led to the fact that, with the struggle against the dominance of religion, this realm has gradually disappeared in the West. 'Nothingness' has taken its place ${ }^{18}$. Today the great religions must confront the task of teaching others to allot a place for the dead in society and in symbolic orders and to overcome the impermeable border between the living and the dead. It is not a matter of obliging the secular world to believe in the beyond, but rather in finding an adequate acquaintance with the inaccessibility of the dead and their individual life histories, one that is indeed beyond a senseless annihilation. This begs the question whether the dead are the other (the excluded) of the world of the living or, if not, the dead represent the third, the surplus, the exit (openness) of the world of the living, the open rest between the world of the living and its excluded and repressed fears. The question would thus be: if remembrance of the dead - which preserves them in their unavailability, but dedicates to them a moment of presence (in narratives, in art, in worship ...) could play a decisive role in the reconfiguration of public space?

The third contribution can be called "exit-strategy". As mentioned in Chapter Two, the sacred can be seen as a separated realm dominated by religious forces, but it can also indicate a "surplus" not to be represented ${ }^{19}$. The ambiguity of religion reveals itself in the fact that on the one hand it administers, dominates and occupies the sacred sphere (the surplus), but on the other hand it opens realms not to be represented. In this way our world and our symbolic orders do not coincide with themselves because they never represent the "whole" (the totality) but refer to a lacuna which might be seen as exit from all our representations and occupations. Following this concept, "God", "Transcendence", the "Beyond", the "Messiah", the "Canon" etc. are transformations of this fundamental openness and a subversion of all definitive borders and self-identities. Regarding the public space it can be maintained that its place is just the realm beyond the dichotomy between inclusion and exclusion.

18 This is strikingly shown by Hans Dieter Bahr. See Bahr 2002.

19 Laurens ten Kate expresses the phenomenon of a promise which transcends its representation and therefore serves as exit of our closed symbolic order very accurately in his article "Secularity as Sacrifice. Notes on the Dialectical Logic in Modernity and its Monotheistic Prefigurations": "The [...] exodus toward desert life has no other goal than wandering; the 'promised land' is not a straightforward goal to be reached after desert life; it is a promise $[. .$.$] that moves on with the wandering journey, so that in the end one does$ not know whether the desert is the promised land after all." (Kate 2015, pp. 22-45, here: p. 39). 
By way of conclusion, I would like to bring together the diverse threads of these short considerations: the Christian narrative, as one of the basic narratives of Europe, is bound up with the genesis of a public sphere, which is pluralistically accessible and needs to be continuously reconfigured, i.e. it does not exclude anyone on the basis of origin, gender, social class, income, sickness, or creed, and it even includes the dead.

Today it is especially important to listen to the voices of migrants in this space and formulate a new peace narrative of a public sphere shared by people from the Judeo-Christian, secular and Muslim traditions. This includes that civil society supports the religions, today in particular Islam, in giving expression to their own traditions and their affective richness. Moreover, this means learning from the religions that the dead - in a way to be newly defined - are to be given an appropriate place in the constitutive narratives of civil society. What is not to be forgotten here is that public space lives from an ethos that evades both the dichotomy of inclusion/exclusion as well as the totality claims that annihilates all particularities and thus the body of the other. Rather, public space begins precisely where these dichotomies and fantasies of power are undermined, and openings emerge in the representations of dominating power (and their places and times). It is only at the point where these subversive openings come together to be creatively molded into a stream of shared narratives that Europe actually may be said to begin.

\section{Biography}

Since 2011, Kurt Appel has been a Professor of Theologische Grundlagenforschung (Fundamental Theology) at the Institute for Systematic Theology and Ethics at the Faculty of Catholic Theology at the University of Vienna. $\mathrm{He}$ is Speaker of the Research Centre "Religion and Transformation in Contemporary Society" (University of Vienna; established as a research platform in the year 2010). Since 2010, Appel has also been frequently engaged as a Visiting Professor at the Facoltà teologica dell'Italia Settentrionale (Milan), Facoltà teologica dell'Emiglia Romagna (Bologna), the Dipartimento di lettere e di filosofia, Università di Trento and Facoltà Valdese di Teologia (Rome). He studied Theology and Philosophy, German philology and History at the University of Vienna. 


\section{Bibliography}

Agamben, Giorgio: Il tempo che resta. Un commento alla "Lettera ai Romani". Torino: Bollati Boringhieri, 2000.

Appel, Kurt: "Gott - Mensch - Zeit. Geschichtsphilosophisch-Theologische Erwägungen zu Neuem Humanismus im Ausgang von Bibel, Hegel und Musil", in: idem (ed.): Preis der Sterblichkeit. Christentum und Neuer Humanismus. Freiburg/Wien: Herder, 2015, pp. 19-6o.

Bahr, Hans-Dieter: Den Tod denken. München: Fink, 2002.

Berger, Peter L.: A Rumor of Angels. Modern Society and the Rediscovery of the Supernatural. New York: Anchor Books, 1970.

Certeau, Michel de: Le fable mystique, 1. XVI ${ }^{e}-X V I I^{e}$ siècle. Paris: Gallimard, 1982.

Denk, Andreas: "Der Raum der Wand als Bedeutungsträger. Architektur als Ausdrucksmittel in der Stadt", in: Vittorio Magnago Lampugnani/Rainer Schützeichel: Die Stadt als Raumentwurf. Theorien und Projekte im Städtebau seit dem Ende des 19. Jahrhunderts. Berlin/München: De Gruyter, 2017, pp. 263-275.

Habermas, Jürgen: The Structural Transformation of the Public Sphere: An Inquiry into a Category of Bourgeous Society. Translated by Thomas Burger and Frederick Lawrence. Cambridge: MiT Press, 1991.

Harvey, David: Rebel cities. From the right to the city to Urban revolution. London/New York: Verso, 2012.

Illich, Ivan: The Rivers North of the Future. The Testament of Ivan Illich as Told to David Cayley. Toronto: House of Anansi Press, 2005.

Kate, Laurens ten: "Secularity as Sacrifice. Notes on the Dialectical Logic in Modernity and its Monotheistic Prefigurations", in: J-RAT 1 (1/2015), 22-45.

Metz, Johann Baptist: Memoria Passionis. Ein provozierendes Gedächtnis in pluralistischer Gesellschaft. Freiburg: Herder, 2006.

Nancy, Jean Luc: La déclosion. Deconstruction du christianisme, 1. Paris: Galilée, 2005.

Neri, Marcello: "Nach dem Ende der Institutionen der Moderne. Christentum und Europa: ein gemeinsames Schicksal", in: Kurt Appel/Isabella Guanzini/Angelika Walser (ed.): Europa mit oder ohne Religion? Der Beitrag der Religion zum gegenwärtigen und künftigen Europa, Göttingen: Vandenhoeck \& Ruprecht/Vienna University Press, 2014, pp. 183-203.

Pamuk, Orhan/Gun, Guneli: Snow. London: Faber \& Faber, 2004.

Sassen, Saskia (ed.): Global Networks, Linked Cities. London: Routledge 2016 [2002].

Sequeri, Pierangelo: Il sensibile e l'inatteso. Lezioni di estetica teologica. Brescia: Queriniana, 2016.

Tracy, David: The Analogical Imagination: Christian Theology and the Culture of Pluralism. New York: Crossroad, 1981. 
Zenger, Erich: Gottes Bogen in den Wolken. Untersuchungen zu Komposition und Theologie der priesterschriftlichen Urgeschichte. Stuttgart: Verlag Katholisches Bibelwerk, 1983 .

Translated by Patrick Elridge and Paul Bowman, revised by Kurt Appel. 